\title{
Proceeding
}

Supplementary Issue: Spring Conferences of Sports Science. First International Conference in Iraq on Sport for Peace, 4 April 2019. Baghdad Science Institute, Baghdad, Iraq.

\section{The effect of continuous training on myoglobin muscle and on some specific fitness elements and basic skills of badminton players}

\author{
ABEER DAKHIL HATEM AL-SELMI ${ }^{1}$, SUAD SABTI AL-SHAWI ${ }^{1}$, SHILAN HUSSEIN MOHAMMED ${ }^{2}$ \\ ${ }^{1}$ College of Physical Education and Sport Sciences for Women, University of Baghdad, Iraq \\ ${ }^{2}$ College of Physical Education, University of Sulaimani, Iraq
}

\begin{abstract}
The current study problem can be described in the form of the following question and the following subquestions as follows: What is the effect of continuous training in Mayoklobin muscle and on some of the special fitness elements and basic skills of badminton players? The following questions stem from this question:1. myoglobin level in muscles?2. What is the level of some fitness elements for badminton players?3. What is the basic skills level of badminton players?. The current research aims to prepare continuous training exercises for the research sample, to identify the effect of continuous training method in the level of muscle myoglobin in the development of certain elements of special fitness and basic skills of badminton players. Methodology: The researchers used the experimental approach in designing the one group with the tribal and remote tests. The research sample consisted of badminton players in the youth club of the At huri Club. The team consisted of (12) players, (2) player for the exploratory experiment, Explosive force (two men) Agility, Flexibility Technical tests Massive strike, front impact, rear strike.1. The researcher's concluded.2. The results showed that the level of myoglobin in the muscles within the normal limits when using the method of continuous training of badminton players.3. Exercise according to the continuous training method has led to the development of some special fitness elements and basic skills of badminton players. Recommend the researchers: to circulate the results of the current study on the sports teams participating in the league in badminton. Keywords: Continuous training; Muscle mycobiont; Some special fitness elements; Basic skills; Badminton players.
\end{abstract}

\section{Cite this article as:}

Al-Selmi, A.D.H, Al-Shawi, S.S. \& Mohammed, S.H. (2019). The effect of continuous training on myoglobin muscle and on some specific fitness elements and basic skills of badminton players. Journal of Human Sport and Exercise, 14(4proc), S435-S441. doi:https://doi.org/10.14198/jhse.2019.14.Proc4.01

Corresponding author. College of Physical Education and Sport Sciences for Women, University of Baghdad, Iraq.

E-mail: abeer@copew.uobaghdad.edu.iq

Supplementary Issue: Spring Conferences of Sports Science. First International Conference in Iraq on Sport for Peace, 4 April 2019. Baghdad Science Institute, Baghdad, Iraq.

JOURNAL OF HUMAN SPORT \& EXERCISE ISSN 1988-5202

(c) Faculty of Education. University of Alicante

doi:10.14198/jhse.2019.14.Proc4.01 


\section{INTRODUCTION AND IMPORTANCE OF RESEARCH}

The players differ in the ability to achieve, although they are subject to the same training procedures and may be due to the fact that a certain function has a greater potential and capabilities than others. Therefore, the quality of the output varies and the individual succeeds in physical and skill performance. The game is integrated in terms of its reliance on the basic requirements of any other sports game. The badminton player needs different energy production systems to perform the competition perfectly. All power systems overlap to supply the working muscles with the necessary enzymes to perform their required constriction, as well as to adapt them to bear fatigue in most competitions. It requires the possession of white muscle fibres and red fibres that are applied to white fibres due to the need of the badminton player (Fattah,2003). The oxygen fibre is characterized by its containment of mycobiont, which helps to transfer oxygen from the cell membrane to the mitochondria to be used in the metabolism of the production of the primary energy enzyme (ATP), which requires the muscles of the working player to be available continuously throughout the duration Performance of exercise or sports competition. This requires a variety of exercises and different speeds, which are dominated by exercises that depend on the system of production of air energy, such as continuous training, which increases the ability of the badminton player to supply muscles oxygen and fatigue to the maximum possible, so the elements of fitness are the main and important in all The conditions of the game to reach a better achievement, and in general that fitness is the broad base and the backbone of the exercise sports activities at all stages of age(Ibrahim Salama, 2009), which sniff out the specific fitness which means the specificity of sport in each individual in terms of direction of The performance and the organic organs involved in the performance to achieve the achievements of advanced sports, where you need and continuously to the capacity of physical and technical skills to meet the different conditions of the game and overcome them. The importance of research in the study of the impact of exercise in accordance with the method of continuous training on badminton players, Training at the level of myclobin in some elements of physical fitness and the basic skills of the research sample, which may help in the development of training curricula and guidance training the right direction, which contributes to raising the level of achievement of the athlete.

\section{Research problem}

Through the experience of the researcher in the field of the game and training, there is a lack of scientific studies related to the study of the biochemical variables that are affected by sports training and the impact of these variables on the development of some elements of fitness and special skills of the basic badminton players, including myoglobin found in the muscle fibre red, which is important, Refers to the existence of a real problem cannot be revealed only by studying and searching for them to produce tangible results in favour of improving the functional organs of the body of the badminton player can be the problem of the current study in the form of question The following sub-questions are as follows:

What is the effect of continuous training in myelophenia muscle and on some special fitness elements and basic skills of badminton players? The following questions stem from this question:

1. The level of myoglobin in the muscles?

2. What is the level of some fitness elements for badminton players?

3. What is the level of basic skills of badminton players?

\section{Research objectives: The current research aims to identify}

- Preparation of continuous training exercises for the research sample.

- Recognize the effect of the continuous training method in the level of muscle myoclubin in the development of certain elements of special fitness and basic skills of badminton players. 


\section{Research hypotheses}

- There are statistically significant differences between the tribal and remote tests in the level of muscle myoclubin and the development of certain elements of special fitness and basic skills of badminton players(Al-Khashab, et al,1988).

\section{Research areas}

Human Field: A sample of young badminton players.

The Azerbaijani domain: The period from 1/11/2017 until 11/1/2018.

Sphere: The inner hall of the club's archaeological court.

\section{METHOD AND FIELD PROCEDURES}

\section{Research methodology}

The researchers used the experimental approach to design a single set of tribal and remote tests to suit the nature of the research problem.

\section{The research community and its sample}

The sample of the research was tested in a deliberate manner and consisted of badminton players for the youth club of 12 players, (2) players for the exploratory experiment, randomly selected from the research community and excluded from the research community (Hussein, 1980).

\section{Tools and equipment used in the research}

The researchers used many tools and equipment in their work: chalk, tape measure length $(50 \mathrm{~m})$, siren, wood panel $40 \mathrm{~cm}$ long and $20 \mathrm{~cm}$ width, 30 meters, Burke, stadium, Plush number 8 , volleyball court number 2, feather feathers, jet feather balls, and muscle level reading machine (Naji \& Ahmed, 1987).

\section{FIELD RESEARCH PROCEDURES}

\section{Selection of fitness elements and tests}

It was distributed to a group of experts specialized in the field of training and fitness and identified the most important elements of fitness suitable for badminton players.

\section{Exploration experiment}

In order to ascertain and determine the conditions of application of physical and skill tests, the tests were carried out on a sample of 2 randomly selected players who were excluded from the main experiment on 1/11/2017. Experience that the tests are clear (Rahman Qaba, 1989).

\section{Tribal measurements and tests}

The researchers conducted the tribal tests for two days, and the first day measured the percentage of myoclubin by taking a blood sample and taking it to the laboratory (laboratory judgment) in Baghdad on Monday (6/11/2017) and 7/11/2017) physical and technical tests at the stadium of the Athuri Club and the following was carried out:

\section{Measuring the level of myoclubin in muscles}

Measurement Objective: Know the level of myoglobin muscle. 
Method of measurement: The blood is withdrawn by $5 \mathrm{~cm}(3 \mathrm{~cm})$ of the sample and placed in White Tube. The serum is extracted from it and placed in the Centrifuge inside the Siemens Immunoassay Systems reading machine (El-Sayed Farahat, 2003).

Registration

The result of the device is taken and certified as a level of blood glucose, measured in milligrams ( $\mathrm{ng} / \mathrm{ml}$ ).

\section{Physical tests}

1. Explosive force (arms) (Mohammad Hassan Allawi and Mohamed Nasr al-Din Radwan: 2000)

2. The explosive force (two men) (Mohammad Hassan Allawi and Mohamed Nasr El-Din Radwan: 2000)

3. Fitness (QaisNaji and Bastoise Ahmed: 1987)

4. Matawla (QaisNaji and Bastoise Ahmad: 1987)

5. Flexibility (Mohamed SubhiHassanein: 2007)

\section{Technical tests: (Moin Taha: 2001)}

1. The overwhelming blow.

2. The front blow.

3. The rear strike.

\section{MAIN EXPERIENCE}

The researchers prepared special exercises to develop some elements of special fitness and basic skills according to the method of continuous training characterized by medium intensity and large volume (roper, 1995)]. The duration of the training curriculum lasted 8 weeks in the general preparation phase with three training modules (Saturday, Monday), On Wednesday (8/1/2018), the researchers used the sample to exercise heavily $(50-70 \%)$ of the maximum capacity of the sample and the relatively low rest intervals between repetitions so that the pulse fluctuated during the exercise performance between (130 - 140) beats per minute, and begin the training exercises warm up to prepare all the muscles of the body and end exercises relaxation and relaxation, (3) with 4 small courses for each intermediate course. Gradual increase in the continuous load during the two intermediate courses were carried out by increasing distances while reducing the size of the training load in the fourth week of each session. The exercises were carried out in the main part of the training module, (50-70) Minute, and running exercises ranged during the training modules (Mohammed Jassim et al, 2014).

\section{Post-tests}

Post-tests were carried out by the same tribal testing method. Blood samples were drawn for the purpose of measuring my elope with blood and conducting field tests on the date of 11/1/2018.

\section{Statistical means}

The Statistical SPSS was used to process data and statistical methods.

\section{PRESENTATION, ANALYSIS AND DISCUSSION OF RESEARCH RESULTS}

The value of (t) the table is 2.31 at the degree of freedom of 9 and the level of significance 0.05 , as show in table (1). 
Table (1) shows an increase in the level of myoclubin in the muscles. The researchers attribute this to the effectiveness of the exercises that proved their significance when applying the training method to the study sample according to the method of continuous training. "Myoglobin increases in the human muscles under the influence of sports training". Mycoplubin is the most important protein in the muscle and its mechanism of action depends on transferring the largest amount of oxygen.

Table 1. Statistical treatments for the tribal and remote tests of the research variables

\begin{tabular}{|l|l|l|l|l|l|l|l|}
\hline \multirow{2}{*}{ Significance } & \multirow{2}{*}{ Value $\mathrm{t}^{*}$} & \multicolumn{2}{|c|}{ The first test } & \multicolumn{2}{|c|}{ Measuring unit } & \multirow{2}{*}{ Measuring unit } & \multirow{2}{*}{ Variables } \\
\cline { 3 - 6 } & & $\mathrm{h}$ & $\mathrm{s}$ & $\mathrm{h}$ & $\mathrm{s}$ & & \\
\hline Spiritual & 24.739 & 3.508 & 45.73 & 3.504 & 37.96 & $\mathrm{Ng} / \mathrm{ml}$ & Almayoklopan \\
\hline Spiritual & 2.78 & 0.88 & 12.63 & 1.87 & 14.54 & $\mathrm{Cm}$ & Medical throw a ball weighing (3) \\
\hline Spiritual & 15.34 & 4.76 & 1.82 & 9.50 & 1.70 & $\mathrm{Cm}$ & Jumping stability with both hands \\
\hline Spiritual & 11.97 & 0.44 & 13.27 & 0.04 & 14.01 & $\mathrm{Sec}$ & Ran Shuttle \\
\hline Spiritual & 20.10 & 0.19 & 25.10 & 7.22 & 26.55 & $\mathrm{Sec}$ & 300 ran away \\
\hline Spiritual & 9.30 & 0.18 & 5.53 & 0.47 & 7.24 & $\mathrm{Cm}$ & Flexible trunk \\
\hline Spiritual & 3.024 & 0.448 & 34.7 & 1.093 & 33.2 & degree & Crushing blow \\
\hline Spiritual & 6.43 & 3.53 & 30.54 & 2.42 & 25.92 & degree & Hit the front \\
\hline Spiritual & 6.71 & 3.37 & 25.90 & 3.12 & 21.44 & degree & Background strike \\
\hline
\end{tabular}

Near the muscle cell membrane to the energy houses (mitochondria) to produce sufficient quantities of the essential energy enzymes (ATP) necessary for the performance of frequent muscle contractions needed by the badminton player, Muscles to increase the availability and activity of myoglobin depending on the level of effort needed by this athletic activity, (Taha, 2001) and this is what happened in the sample of the study of an increase in The level of myoglobin when applied to exercises, which relied on exercises on the system of production of air energy, as "aerobic exercises increase the proportion of myoglobin in the muscles of the body of all sports from (330) millilitres to up to (550) millilitres" (BahaaEddin Salama: 2009) The researcher explained the reasons for the development in some elements of fitness that the basis of physical fitness possess athletic physical abilities and mobility in general and integrated to achieve high achievements, and that the specificity of badminton requires a certain kind of fitness elements and does not prefer to prefer one element to another, (Qassim Hassan Hussein) : 1980) (Abdel Zaid, 2008). The researchers see that followup level of myklubin in the muscles of the badminton player is necessary because lack of it leads to disruption of the process of transferring oxygen from outside into the muscle cells and therefore affected muscles working in the performance of muscle contractions needed by the player as a result of delay or stop production of the enzyme energy three (ATP) for the lack of oxygen necessary for the process of metabolism that occurs within the muscle cells (Al-Zayyud \& Amer Alian,2005), and that the development of the sample after the exercise after exercise is a number of positive changes in the muscles, because "the process of regularity in the training leads to the occurrence Changes in the body's various cells and tissues (Sobhi Husseinin). The changes that occur after aerobic exercise are improved muscle function in the case of oxygen availability. This improvement is mainly achieved by increasing both mycellin and the mitochondria, as well as by increasing muscle glycogen stock, Increased activity of enzymes and can also increase the ability of muscles used on fat consumption and use as energy to drive muscle work "(Mohamed Osman: 1990) The results of the tables showed developments in physical abilities, where the ability of players to perform easy movements and complex to achieve (Nahida Abdel Zaid: 2008). Fitness or lightness is a vital and important element without any sport. It is one of the most effective physical qualities in performance, especially in badminton. The player performs different and consecutive skills in different directions. As fast as possible in addition to the movements of rotation and rotation and balance and change the situation at high speed that fitness is a fundamental part of the speed of (1995: peter) (Allawi\& El Din Radwan, 2000). 
The researchers attribute the development of the basic skills as a result of the use of exercises in the continuous training method, where both blows are almost similar in technique, the blow of the forward front, the process of beating in depth to the back line of the opponent's stadium in the form of a large arc, the strike hit the feather on the foot in front of the head The bat goes down after the beating, which means that the two batches need to raise and jump up the vertical jump and for the purpose of obtaining the strength of a big blow must be coordinated (Othman, 1990)], muscle work of the units of motor and starting muscles jump strength of the two men and ends the muscles of one arm and points 1988). "The player's sense of joint placement and the degree of muscular tension gain the ability to assess the extent of muscle contraction necessary (Borrmann, 1974: g).

\section{CONCLUSIONS}

1. The results showed an increase in the level of myoclubin in the muscles within its normal limits when using the method of continuous training of badminton players.

2. The exercise according to the method of continuous training to develop some elements of physical fitness and the basic skills of badminton players.

\section{RECOMMENDATIONS}

1. Circulate the results of the current study on the sports teams participating in the league in badminton.

2. To monitor differences in the level of myclobin in athletes and to avoid the cases of negative increase or decrease affecting their organs.

\section{REFERENCES}

Abul-Ela Ahmed Abdel Fattah. (2003). physiology of training and sport: Cairo, Dar Al-Fikr, p. 380.

Salama, B. E. D. I. (2009). Physiology of Physical Effort. Dar Al-Fikr Al-Arabi, Cairo, 19.

Zuhair Al-Khashab: Others.(1988). Football, Dar al-Ketub for printing and publishing. University of Mosul, p. 223.

Qassem Hassan Hussein.(1980). Learn the rules of fitness, 1, Dar al-Fikr for printing, Amman.

Qais Naji, Bastoise Ahmed. (1987). Tests and principles of mathematical statistics. Higher Education, Baghdad,p. 398,399.

Ammar Abdul Rahman Qaba.(1989). Sports Medicine: (Mosul, Dar Al Kut Books and Publishing).

Laila El-Sayed Farahat. (2003). Measurement and Testing in Physical Education, 1, Cairo, The Book Center for Publishing.

Moqdad Mohammed Jassim and others. (2014). Evaluation of the level of fitness for students of the fourth stage in the Faculty of Physical Education / University of Babylon, research published in the Journal of the University of Babylon, Humanities, vol. 22, No. 3.

Moin Mohamed Taha.(2001). The impact of training program different feathers in the development of skills of the game of flying feather, unpublished doctoral thesis, College of Sports Education University of Baghdad, p. 61,66.

Mohamed Sobhi Husseinin: Evaluation and Measurement in Sports Education.

Mohamed Hassan Allawi and Mohamed Nasr El Din Radwan. (2000). Measurement in Physical

Education and Sports Psychology - Cairo - Arab Thought Department, p. 136,44.

Mohamed Othman. (1990). Encyclopedia of Athletics, Training of Arbitration Education, I 1: (Kuwait, Dar Al-Qalam for Publishing and Distribution). 
Nader Fahmi Al-Zayyud and Hisham Amer Alian (2005). Principles of Measurement and Evaluation in Education, 3, Amman, Dar Al-Fikr Publishing and Distribution.

Nahida Abdel Zaid. (2008).Fundamentals in Motor Learning, 1, Najaf, Dar Al-Diaa for Printing and Design, p. 73.

Borrmann, g.n.a. (1974). Greatturnen sport rerlaybarlin, p92.

Peter Roper(1995). Thesk; ills of the came badminton, uk.104p.

\section{(c) $\underset{\mathrm{EY}}{(\mathrm{NQ} \mathrm{ND}}$}

This work is licensed under a Attribution-NonCommercial-NoDerivatives 4.0 International (CC BY-NC-ND 4.0). 